\title{
Consummation Anyway: A Reformed Proposal
}

\author{
N. Gray Sutanto \\ Reformed Theological Seminary
}

\begin{abstract}
The central claim of a Consummation Anyway (CA) model is that God could bring about eschatological consummation sans the fall-the intended telos of created humanity-apart from the incarnation of Christ. As such, the CA model is an alternative to an Incarnation Anyway (IA) model, according to which Christ's incarnation is a necessary means by which a state of eschatological glory would be achieved sans the fall. This essay seeks to propose an argument for the CA model by drawing from the covenant theology of the Reformed tradition, and it moves in four steps. Firstly, I shall summarize Marc Cortez's recent arguments for IA, homing in on the major moves that are most relevant for sketching a CA model. Secondly, I will highlight the challenges Cortez has offered against those interested in defending a CA model. Thirdly, I shall sketch a Reformed account of the CA model that seeks to address Cortez's objections. Fourthly, then, I'll consider two potential objections against the sketch I have offered for CA, inspired by a recent argument offered by James T. Turner (2019). Finally, I close with a brief conclusion that summarizes some salient features of the proposed thesis. This paper thus proposes at least one way in which the CA thesis could remain a real and live option within this debate.
\end{abstract}

Debates on Incarnation Anyway (IA) continue apace in current theological discourse, and the range of theological loci involved in this go far beyond Christology per se, including reflections on God's decrees, anthropology, the relationship between nature and grace, theological epistemology, and eschatology. ${ }^{1}$ Arguments for IA typically, and roughly, involve at least these two claims (1) a state of eschatological glory that goes beyond nature for God's people was the intended goal of creation and (2) that Christ's incarnation is a necessary or essential means by which that eschatological consummation is achieved. Hence, regardless of humanity's fall into sin, the second person of the Trinity would have graciously become incarnate anyway

${ }^{1}$ Adams (2006) Van Driel (2008), Crisp (2016 and 2019)

Journal of Analytic Theology, Vol. 9, Summer 2021

10.12978/jat.2021-9.1300-65182014

(C) 2021 Nathaniel Gray Sutanto • (C) 2021 Journal of Analytic Theology 
in order that nature's telos could be fulfilled. Hence, so the argument goes, incarnation anyway.

In a recent work, Mark Cortez continues this lively discussion by considering four objections or alternatives to IA (Cortez 2017, 84-98). The first involves an argument from the Bible to the effect that the incarnation seems to be most linked to redemption, rather than creation and consummation. The second is what he calls "Consummation Anyway," which argues that consummation sans the fall could have been achieved apart from the incarnation. The third is the "no consummation" view, according to which creation does not presuppose a teleological end towards a consummate greater glory. The fourth objection is the "sin anyway" thesis, a kind of felix culpa argument according to which consummation and incarnation presuppose the ordination of sin as a means by which God brings about greater good. After outlining the reasons given for these objections, Cortez responds to each of them, concluding that none of these objections are conclusive in rejecting IA.

While I am sympathetic to Cortez's project, this paper focuses on the second of these alternatives: "Consummation Anyway" (CA), and proposes a version of this argument that, if successful, evades Cortez's main objections against it. Such a proposal involves retrieving some classical Reformed orthodox distinctions, with the aid of the Westminster Standards, Francis Turretin, and the work of the $19^{\text {th }}$ century Reformed theologian Herman Bavinck. The rest of this essay, then, moves in four steps. Firstly, I shall summarize Cortez's arguments for IA, homing in on the major moves that are most relevant for sketching a CA model. Secondly, I will highlight the challenges Cortez has offered against those interested in defending a CA model. Thirdly, I shall sketch a Reformed account of the CA model that seeks to address Cortez's objections. Fourthly, then, I'll consider two potential objections against the sketch I have offered for CA, inspired by a recent argument offered by James T. Turner (2019). Finally, I close with a brief conclusion that summarizes some salient features of the proposed thesis. This paper thus proposes at least one way in which the CA thesis could remain a real and live option within this debate.

\section{Cortez on IA}

This section focuses on what I take to be the most important portions of Cortez's argument for IA, as well as those portions that I take to anticipate his arguments against the CA objection. As I've read the work, Cortez's argument for IA is not meant to be decisive but as a fitting building block for his larger thesis that the incarnation is central for a properly theological account of humanity. At the heart of his argument for IA is a theological reading of the salient passages in 1 Cor. 15. Consider the following passage:

If there is a natural body, there is also a spiritual body. Thus it is written, "The first man Adam became a living being"; the last Adam became a life-giving spirit. But it is not the spiritual that is first but the natural, and then the spiritual. The first man was from the earth, a man of dust; the second man is from heaven. (1 Cor. 15:44b-47) 
Observing the sequence of verse 46, Cortez observes that the spiritual follows after the natural, and that we should follow the majority of recent scholarship in taking the contrast in verse 47 between the earthly man and the man "from heaven" as a qualitative contrast, rather than a contrast of origin (Cortez 2017, 72). The contrast, in sum, then, is that the body of the first man Adam was earthly in quality, whereas the second (and last) Adam, has a qualitatively heavenly body. There is a contrast of quality between Adam's body and Christ's heavenly body.

The question that should be settled now is whether this contrast between the two heads of humanity is one between a fallen body with a heavenly one, or between a natural or created body with a heavenly body. While Cortez notes that fallen humanity is in view in verses 20-23 of this chapter, Paul pivots into a discussion of the creational body in verses 35-49. Verses 20-23, like Rom. 5, focuses on the contrast between Adam as the head of fallen humanity, and the resurrected Christ as the first-fruits of the redeemed, being the first among many to be resurrected from the dead. In verses 35-39, however, Paul deals with a contrast between humanity as created, and the heavenly body as the qualitatively superior, eschatological body. Cortez offers two reasons for this exegetical move. Firstly, he notes that the observations about particular kinds of bodies in verses 36-41 are meant to show that God has designed each body to have its own distinct forms of glory, sans the fall. Secondly, Paul appeals explicitly to Gen. 2:7 in verse 45, a passage that locates Adam in the pre-lapsarian order, in order to ground his argument that the natural comes first, before the spiritual in verses $44 \mathrm{~b}$ and 46 . The contrasts Paul observed in verses 42-43 thus denotes the distinction between created and consummate bodies: the former is "perishable, dishonourable, and weak, unlike the spiritual which is imperishable, glorious, and powerful" (Cortez 2017, 81).

The upshot, especially in view of the "if-then" logic of 1 Cor. 44b, is that "Jesus comes not just as the one who addresses what went wrong in the fall (15:20-23), but also as the one who advances creation toward its intended telos (15:35-49)" (Cortez 2017 , 83). Though Cortez does not cite him, this reading is consonant with the reading of Geerhardus Vos, a professor at Old Princeton and the so-called father of Reformed biblical theology, who, in 1912 made the following observation about the same passage: "It will be noticed, however, that in verses 45,46 the Apostle generalizes the antithesis so that it no longer concerns the body exclusively, but the whole contrast, that relating to the pre-eschatological period, so as to make it cover no longer the reign of sin, but the order of things established in creation" (Vos 1980, 106). Indeed, Vos would then agree with Cortez's conclusion that "Paul is outlining the only true telos of the human person: eschatological consummation" (Cortez 2017, 83).

It is worth noting, then, that at this point proponents of CA would thus heartily agree with the exegesis of 1 Cor. 15 . The contrast between the created body and the heavenly body is a contrast between the state of innocence (or protology), and the state of glory (eschatology). Moreover, there is a clear logical link between the two, as established in 1 Cor. 44b: if there is a natural, then there is a spiritual, namely, if there is a creational order, then there is an eschatological consummation that moves natural, created bodies, into heavenly, glorious bodies.

Here is where Cortez presents a dilemma for those who follow this train of reasoning, specifically in relation to the incarnation: 
If Jesus is so central to the meaning and actualization of true humanity, then must we affirm that the incarnation would have happened even if humanity had never fallen into sin? Or should we maintain instead that the incarnation has redemption from sin as its exclusive focus and argue that God could have brought humans to eschatological consummation in some other way? If the former is true, then we have another reason for maintaining the fundamental significance of Christology for understanding anthropology. If we affirm the latter, however, that would at least raise some challenging questions since it seems to affirm the possibility that humans could have accomplished their true telos even if the incarnation had never happened. In that case, the humanity of Christ is not fundamentally necessary for being or understanding humanity. (Cortez 2017, 83-4)

Proponents of CA would advocate for the latter view, that humans could have accomplished their true telos even if the incarnation had never happened. It does not follow that Christ's humanity now is not important for understanding humanity-he shows us perfect and obedient humanity as the second and better Adam, representing humanity as the redeeming federal head. But it does follow that Christ is not "fundamentally necessary" to understand humanity-that is, it does reject the inference that it would be impossible to understand humanity apart from Christ.

Though Cortez argues that his argument about the centrality of the incarnation for understanding humanity still holds whether or not one affirms IA, he does offer a few reasons for adopting the IA thesis as a fitting implication of his reading of 1 Cor. 15. Drawing from the recent work of Adams (2006), Van Driel (2008), and Crisp (2016), he argues that the incarnation is (1) the means by which all of creation is united to a single head (2) that Christ is "essential" to eschatological consummation and (3) that Christological union is the fitting means by which God had ordained to be united with humanity. In each of these lines of reasoning, Christ is fitting or essential for the bringing about of consummation (Cortez 2017, 86-90).

It is at this point that Cortez brings up the four possible objections against IA, and I will now focus on the second of these, on the CA model, and his objections against this model.

\section{Challenges for a CA model}

The central claim of a CA model is that God could bring about consummation sans the fall-the telos of created humanity-apart from the incarnation of Christ. Cortez acknowledges that one benefit of this model is that it "would thus be able to affirm many of the key aspects of the above arguments without granting that the incarnation would have happened even if creation had never fallen" (Cortez 2017, 93). From here, however, Cortez raises two objections: (1) that such a proposal is overtly speculative and (2) that such a proposal involves the claim that humanity is capable of transitioning from creation to consummation apart from intervening grace.

These two objections, however, coalesce, in that they are implications that follow if one does not suppose that the incarnation of Christ is necessary to achieve 
the greater good of consummation. That is, if the incarnate Jesus is not fundamentally necessary for humanity to achieve their eschatological end, then there must be some other way to achieve that goal independently of Jesus. But we do not know if there is another way - all we have is that Christ indeed was the way. So, the CA model must "pry into counterfactual realities about what might be," rather than making theological judgments about what is the case, or what was actually revealed (Cortez 2017, 93).

The second objection is also an implication of denying that the incarnation is necessary for eschatological consummation. Cortez's reasoning here is as follows: Grace is necessary for humanity to achieve its eschatological end. That grace is encapsulated in the incarnation of Christ. Hence, it follows that the incarnation is necessary to achieve humanity's eschatological end. If one denies the incarnation, then, one must also deny that grace is necessary for humanity to achieve their eschatological end.

The two challenges Cortez raises, then, are actually also two further reasons why Cortez thinks an IA model should be opted over a CA one, as proponents of CA would have to wrestle with the seemingly theologically undesirable consequences of rejecting IA: Reject IA and you end up with speculation and the problematic claim that grace is unnecessary for consummation. The two arguments, then, could be summed up as follows-let us call the first argument the argument from speculation, and the second as the argument from the necessity of grace:

Argument 1 - the argument from speculation:

1. If one rejects that the incarnation of Christ is not necessary to achieve eschatological consummation, then one must find some other way that must be necessary to achieve eschatological consummation.

2. It is not the case that one must find some other way that must be necessary to achieve eschatological consummation.

3. The incarnation of Christ is necessary to achieve eschatological consummation.

These reasons are given in order to support the second premise:

4. In order to find another way that must be necessary to achieve eschatological consummation, one would have to speculate beyond the bounds of what has been revealed.

5. To speculate beyond the bounds of what has been revealed is theologically misguided.

It follows that this modified form of the second premise follows (which further reinforces the conclusion in (3):

6. One should not reject that the incarnation of Christ is necessary to achieve eschatological consummation, on the pain of misguided speculation. 
Argument 2 - the argument from the necessity of grace:

7. If the incarnation of Christ is not necessary to achieve eschatological consummation, then grace is not necessary to achieve eschatological consummation.

8. If grace is not necessary to achieve eschatological consummation, then nature alone is sufficient to achieve eschatological consummation.

9. It is not the case that nature alone is sufficient to achieve eschatological consummation.

Hence (8) entails the denial of consequent of (7), along with its antecedent. So it follows that:

10. Grace is necessary to achieve eschatological consummation.

11. The incarnation of Christ is necessary to achieve eschatological consummation.

We turn now to a response to these arguments from a CA perspective.

\section{In Defense of CA}

In order to respond to these two objections, I suggest rejecting the second premise of the argument from speculation and rejecting premise seven of the argument from the necessity of grace. Let us begin with the latter move, as disclosing how God could bring about the eschatological end of humanity by his free benevolence, but without the incarnation, also respond to the argument from speculation.

God's condescending goodness, indeed, is necessary in order for natural humanity to achieve their consummate (and supernatural) end. And here the Reformed tradition provides some aid by their articulation of covenant theology. Indeed, according to the Reformed tradition, Jesus Christ brings those in union with him into their consummate telos not because the incarnation per se is necessary to bring about that consummation, but because God has decided to work with humanity covenantally through a federal head - a federal representative, in Christ and in Adam. Not only so, the rewards of covenantal obedience, too, is disproportionate to the nature of the obedience itself. Consider, here, the language of the first article of chapter seven of the Westminster Confession of Faith (WCF), on the covenant between God and humanity:

The distance between God and the creature is so great, that although reasonable creatures do owe obedience unto him as their Creator, yet they could never have any fruition of him as their blessedness and reward, but by some voluntary condescension on God's part, which he hath been pleased to express by way of covenant. (WCF 7:1)

Notice that the prospect of having God as humanity's "blessedness and reward" (in the beatific vision), is contingent upon a "voluntary condescension on God's part," 
which is, in turn, expressed by way of covenant. A covenant, then, is God's voluntarily promising himself to man, on the condition of humanity's obedience to the terms and sanction of that covenant. As such, because the reward is only promised by way of covenant, one might say that there is a disproportionality between the supernatural reward promised and the natural obedience owed. While the Westminster Standards avoid the language of grace in order to preserve the distinction between God's generosity before the fall and God's gracious dealings with sinful humanity after the fall, Herman Bavinck did not shy away from referring to this pre-lapsarian promise as gracious, provided that this is understood properly. As Bavinck summarizes:

[Human beings] expect salvation and eternal life from him. All this is possible solely because God in his condescending goodness gives rights to the creature. Every creaturely right is a given benefit, a gift of grace, undeserved and nonobligatory. All reward from the side of God originates in grace; no merit, either of condignity or congruity is possible. True religion, accordingly, cannot be anything other than a covenant: it has its origin in the condescending goodness and grace. (Bavinck 2004, 570; cf. Mattson 2010, 72)

The "right" that a creature has to the reward of that covenant, were the creature to offer that obedience, is thus a graced right: "In that sense the 'covenant of works' is not a 'covenant of nature' ... There is no natural connection here between work and reward" (Bavinck 2004, 571). For Bavinck, then a covenant is gracious, not in the qualified post-lapsarian sense that involves the forbearance of sin, but in the sense that it cannot be obligated or coerced out of God, but comes from his free benevolence. Grace, in the sense of God's free benevolence, then, is necessary for humanity to achieve their consummate end.

The Westminster Standards continued to distinguish between a covenant of works with Adam, and a covenant of grace that became necessary in Christ because of the fall. On the former, it says this:

II. The first covenant made with man was a covenant of works, wherein life was promised to Adam, and in him to his posterity, upon condition of perfect and personal obedience. (WCF 7:2)

Notice the logic and trajectory of creation toward consummation embedded within the second article of WCF 7 here. "Life" was promised to Adam and his posterity, upon condition of perfect and personal obedience. The language of life here harkens one back to the first article of WCF 7, namely, the gift of God as one's blessedness and reward. The twentieth question in the Westminster Larger Catechism (WLC) thus associates this first covenant with Adam as a covenant of life:

Q. 20. What was the providence of God toward man in the estate in which he was created?

A. The providence of God toward man in the estate in which he was created, was the placing him in paradise, appointing him to dress it, giving him liberty to eat of the fruit of the earth; putting the creatures under his dominion, and 
ordaining marriage for his help; affording him communion with Himself; instituting the Sabbath; entering into a covenant of life with him, upon condition of personal, perfect, and perpetual obedience, of which the tree of life was a pledge; and forbidding to eat of the tree of knowledge of good and evil, upon the pain of death. ${ }^{2}$

Perhaps an analogy here might help to capture the sense of the Standards and Bavinck's emphases. The rewards that come by way of a covenant are rather distinct from natural rewards. Consider the reward of exercising in the gym. A consistent work-out regimen yields the reward of larger muscles, a healthier cardiovascular system, and a higher metabolic rate. There is thus an intrinsic, natural relationship between regular exercise and a healthier body. But suppose now my wife promises me something: that she would purchase me a new private airplane if I commit myself to a rigorous exercise regimen for an entire year. Now, no amount of exercising can actually generate a new private jet to appear in my name in our local airport. However, by the stipulation of the promise-a covenant-the reward is now tethered to my keeping of that exercise regimen. Though there is no natural connection between a private jet and my exercising, I now, by the grace of my wife, have a right to it were I to keep exercising.

In theological language, then, the rewards tied to a covenant are owed to the covenant-keeper ex pacto. The high orthodox Protestant scholastic Francis Turretin argues that the value of the obedience offered can have no intrinsic purchase "to the infinite reward of life," and as such the gift of the reward depends on the character of the covenant-maker: "the fidelity of him making it" (Turretin 1997, 578). In sum, Turretin argues that this pact was "gratuitous, as depending upon a pact or gratuitous promise (by which God was bound not to man, but to himself and to his own goodness, fidelity, and truth" (Turretin 1997, 578).

This language of life, however, also includes not merely the beatific visionthough that is indeed the central reward for the Christian, having God as their blessedness-but also the attaining of glorious human natures. The ninth chapter of the Westminster Confession makes this clear. In contrast to the will of man in the state of innocence, "the will of man is made perfectly and immutably free to do good alone in the state of glory only" (WCF 9:5). This language distinguishes between the creational goodness that Adam enjoyed, and the immutable goodness that glory bestows. Herman Bavinck, likewise, argued in this way:

the first human beings, being created in God's image, rested in it and saw in this covenant a revelation of $a$ way to a higher blessedness. The covenant of works, accordingly, does justice to both the sovereignty of God-which implies the dependency of creatures and the nonmeritoriousness of all their works - and to the grace and generosity of God, who nevertheless wants to give the creature a higher than earthly blessedness. (Bavinck 2004, 572, emphasis mine)

\footnotetext{
${ }^{2}$ See also the exposition in Van Dixhoorn 2014, 97-8.
} 
Turretin observed the same point:

However, the received opinion among the orthodox is that the promise given to Adam was not only of a happy life to be continued in paradise, but of a heavenly and eternal life (to which he was to be carried after the course of perfect obedience and perseverance had been run and which God had prescribed to him as a trial of his faith)... The question is not whether the promise was given to him of happiness and life perpetually to endure, if he had persisted in integrity... Rather the question is whether that happiness and life were to be passed in heaven or only upon the earth and in paradise. The latter they affirm; we, the former. (Turretin 1997, 583)

Notice, then, that the Westminster Standards, Turretin, and Bavinck offer resources that respond to Cortez's argument from the necessity of grace. They show that denying that the incarnation is necessary (or essential) to achieve the eschatological end does not entail that grace (or, gratuitous free benevolence) is unnecessary to achieve that supernatural end (Premise 7). God has offered a way to achieve that end by the grace of establishing a covenant through the federal headship of Adam. Embedded within the creation of the first humans in paradise is thus the telos of a higher life: consummation anyway is the logic of the Reformed tradition. Grace is indeed necessary, and that grace is manifested in the covenant that made possible Adam's entrance into a higher life, conditioned on his obedience. That is, consummation is the original telos that was possible through Adam's federal headship.

How, then, does Christ fit within this picture? Rather than arguing that the incarnation of the second person of the Trinity per se is what is necessary for humanity to obtain their eschatological end, Christ obeyed in Adam's place, and thus, to borrow Brian Mattson's pithy phrase, Christ has restored us to our destiny (Mattson, 2010). That is, Christ restored us to the blessed destiny that Adam would have taken us, had he remained upright. Again, Bavinck is instructive on this point, and is worth citing in full:

For the Reformed, who walked in the footsteps of Augustine... Adam did not possess the highest kind of life. The highest kind of life is the material freedom consisting of not being able to err, sin, or die. It consists in being elevated absolutely above all fear and dread, above all possibility of falling. The highest life is immediately bestowed by grace through Christ upon believers. They can no longer sin (1 John 3:9) and they can no longer die (John 3:16) since by faith they immediately receive eternal, inamissable life. Theirs is the perseverance of the saints; they can no longer be lost. Hence, Christ does not [merely] restore his own to the state of Adam before the fall. He acquired and bestows much more, namely, that which Adam would have received had he not fallen. He positions us not at the beginning at the end of the journey had Adam had to complete. He accomplished not only the passive but also the active obedience required; he not only delivers us from guilt and punishment, but out of grace 
immediately grants us the right to eternal life. (Bavinck 2004, 573, emphasis mine)

Christ, then, offered an obedience with two aspects, as Bavinck observed here. The passive obedience of Christ is that aspect of Christ's obedience that suffers the conditions of a fallen world and the penal consequences of Adam's disobedience in the fall, having its climax in his death on the cross. Christ's active obedience, however, is that aspect of Christ's obedience that Adam, too, had to offer in the state of innocence to the covenant of works. Notice the conceptual presence and logic of these covenantal features in the description of Christ's work in the WCF 8:5:

The Lord Jesus, by his perfect obedience and sacrifice of himself, which he through the eternal Spirit once offered up unto God, hath fully satisfied the justice of his Father; and purchased not only reconciliation, but an everlasting inheritance in the kingdom of heaven, for all those whom the Father hath given unto him.

Jesus offered both "perfect obedience" and a "sacrifice" of himself, which led to this twofold result: "reconciliation" (which corresponds to his sacrifice of himself), and an "everlasting inheritance in the kingdom of heaven" for those given unto him (which corresponds to his perfect obedience). The everlasting inheritance in heaven is precisely that "life" (in the language of WCF 7:2) which Adam would have inherited for him and his progeny, had he obeyed. Hence those who are in Christ enjoy communion with him in "grace and glory" (WLC 65). The glory of WCF 9:5 is the life offered in WCF 7:2, which in turn was forfeited by the fall, but restored to God's elect in Christ (WCF 8:5; WLC 65).

The upshot, then, of this exposition of these traditional moves in Reformed covenant theology, again, is that denying that the incarnation per se is necessary for achieving the eschatological end does not entail the denial of the necessity of grace for achieving that end. That end could have been achieved, by God's intended covenantal design, by way of the obedience of the original federal head, namely, Adam. Premise seven of the argument from the necessity of grace thus fails.

This leads us directly to a response to Cortez's objection from speculation, and this can be shown in brief. Finding out a way to achieve consummation apart from the incarnation involves no illegitimate speculation beyond the bounds of divine revelation (Premise 2). That Adam's federal obedience to the covenant of works is the way by which humanity was originally meant to enter into consummate glory is embedded within the very texts that Cortez himself exegetes in 1 Cor. 15, the AdamChrist parallel in Rom. 5, and the Genesis narrative itself. The if-then structure of 1 Cor. 15:44b specifically, I suggest, is better read from the model of CA: "if there is a natural body, then there is a spiritual body" involves a logical link between creation and glory as such, not creation and incarnation. One might also note that Turretin invokes the law-rewards principle, according to which a reward to eternal life is promised to law-keeping in the biblical witness. ${ }^{3}$

\footnotetext{
${ }^{3}$ Turretin $(1997,583)$ notes passages like Lev. 18:5, Mt. 19:16-17 and Rom. 7:10.
} 
If Adam would have obeyed with his natural body, he would have moved himself and his progeny to the spiritual state, bestowing upon them their eschatological heavenly bodies, perhaps in the same way that believers who are still alive at the time of Christ's second coming would also receive a transformed body "in the twinkling of an eye" (1 Cor. 15:52). Premise 2 of the argument from speculation, then, also fails to hold up (and, by responding to the two potential objections below, I believe we have further resources to respond to this argument from speculation).

Indeed, not only, as Cortez notes, can CA accommodate his fine reading of 1 Cor. 15, this argument also shows that CA has a venerable precedent within a long line of tradition within the Christian faith, namely, the Reformed tradition.

\section{Anticipating Objections: The Impossibility Thesis and the Problem from Vagueness}

We do well to anticipate at least two objections to the argument above, and thus also to consider how invoking the covenant of works might aid in responding to these objections. Doing so affords us with the opportunity to clarify the argument sketched above, and also further to show that consummation anyway is less speculative than one might first think.

The first potential objection is the Impossibility Thesis (IT), recently raised and clarified by James T. Turner (2019) in his essay "Perfect Obedience, Perfect Love, and the (So-Called) Problem of Heavenly Freedom." While IT is initially raised as an objection to the idea that one can ground the impeccability of consummate human beings in heaven on their freely-lived earthly lives, IT might also have implications for advocates of CA. The objection has to do with the impossibility of those redeemed to change themselves in such a way as to bring about their consummate bodies. By parity of reasoning, then, it is impossible for those in the state of innocence to bring themselves into the heavenly, consummate existence. Turner uses the terms inaugurated new nature (INN) to refer to the redeemed before the second coming of Christ, and consummated new nature (CNN) to refer to the consummate life. Just as it is physically impossible for those with an impaired vision to restore clarity to their eyes, so is it metaphysically impossible for those with redeemed natures to bring about the consummate natures for themselves. In Turner's $(2019,241)$ words:

Now, when I suggest that plausibly it is metaphysically impossible for a human with INN to change her character such that she becomes a human with CNN, I mean it in the same way that one might plausibly suggest that it is physically or nomologically impossible that a human with CVN [Correctable Vision Nature] change her vision, by internal effort, such that she becomes a human with PVN [Perfected Vision Nature]. (Note here that the idea is not that a human could not change from having CVN to having PVN; rather, it is that a human cannot do this through visual training or exercise.)

Mankind in the state of innocence and sinners with an INN are in possession of bodies that fall short of consummation. Hence, in the same way that those with INN would 
not be able to bring about the CNN for themselves, so too, is it impossible for those with innocent natures (like Adam) to bring about the CNN for themselves. Compound this with the idea that the CNN can only take place by the miraculous power of God that brings about the resurrection of glorious bodies. It seems that the transition from INN to CNN requires precisely that: a resurrection. And since resurrection presupposes human death, and human death presupposes the fall, so too does consummation presuppose the redeeming work of Christ on which the resurrection of the redeemed is based. In this story, then, consummation anyway is impossible, for at least two reasons: (1) Adam could not bring about the change from innocent natures to consummate natures, and (2) the resurrection promised by Christ's redeeming work is that which is necessary to bring about the transition into glory.

What might proponents of CA say to this objection? Notice that the covenant idea once again comes to aid us. Proponents of CA here would heartily agree that Adam could not, "by internal effort" bring about the consummate nature for himself. Indeed, proponents of CA would argue that the transition from innocence/regeneration unto consummation is not one of gradual ascendency but of a real qualitative transition from two non-overlapping sources. Again, the consummate (and resurrected) body is spiritual precisely because it comes from the power of the Spirit. Only God can bring about this transition.

The covenant of works protects the divine origins of this transition. It is not Adam's obedience that naturally brings about the consummate body. No amount of obedience from Adam can bring it out, just as no amount of my exercising in the gym can magically bring about an airplane under my name to appear in the local airport. The consummate body is granted to Adam by God's free benevolence in setting up the covenant of works-it arises from the promise and power of God, tethering this disproportionately glorious reward to Adam's finite obedience.

The response to the idea that the resurrection is necessary to bring about the consummate natures, too, can be responded to in brief. Just as believers who are still alive during Christ's second coming would instantly receive their transformed, consummate bodies (recall 1 Cor. 15:52), so too would Adam, had he obeyed, receive a transformed, consummate body. What is required to bring about the consummate body is thus not resurrection per se, but a miraculous working of God's initiativeeither by way of resurrection or by way of instant transformation.

This brings me to the second, perhaps more serious, potential objection, that is, the objection from vagueness. Suppose we grant that the consummate body is granted to Adam when Adam obeys. The question here is: how many times must Adam obey, and what particular kind of obedience must Adam offer, in order to receive the reward of the covenant of works? The stipulations of the covenant seem to be exceedingly vague: should Adam obey once, twice, or three times? To make matters worse, it seems that offering an answer to this objection involves no small amount of speculation.

An initial response to this worry is by clarifying that the obedience that Adam was to offer to God is not to be conceived of quantitatively, as a collection of a numerical sum of obedient acts. Rather, just as the "one act" of righteousness in Romans 5:12-18 refers not to a singular act by Christ, but rather to the whole of his 
life and work as a completed act of obedience, so too must Adam offer an obedience that is "complete" before God.

But what, exactly, does this completion look like? What is the omega point, one might ask, of his covenantal obedience? Sceptics of CA might contrast the difficulty of specifying how Adam might complete this obedience to the clarity of the biblical witness concerning the completion of Christ's obedience. It was precisely at the point of death on the cross that Christ declared that his obedience is finished (cf. John. 19:30 and Phil. 2:6-11). Embedded within this account is perhaps another argument to the effect that Christ's work of redemption is a necessary pre-requisite to bring about glorious bodies for the redeemed: Christ had to offer himself as a sacrifice, become the first fruits of those who would be resurrected, in order that we too might partake of the consummate life. Hence, instead of speculating about CA, why not simply follow the biblical plotline that seems to imply that it is Christ's completed obedience-to the point of death-that brings about consummate estates? This is not so much an endorsement of incarnation anyway (IA) but a rejection of consummation anyway as the original telos of Adam.

While a full response to this objection would take us beyond the scope of this paper (requiring, I think, a full biblical-theology of the covenant and the work of Christ as the second Adam), I think a preliminary response can be canvassed in the following way.

Granting the biblical witness that suggests that Christ comes as the second Adam, fulfilling that which Adam had failed to complete, we can infer that Christ's life tells us exactly what is required for Adam to offer complete obedience sans the fall. Christ was led by the Spirit to be tempted in the wilderness, for example, in order to recapitulate the temptation of the serpent against Adam in the garden. Christ was also sent to crush the serpent (Gen. 3:15), and this is precisely what his death on the cross had accomplished-all things were subjected to him in his exaltation. His death succeeded this because he had "disarmed" the rulers and authorities by "cancelling the record of debt that stood against us" (Col. 2:14-5). I take this to mean that Christ had to obey and die in our place in order to disarm the serpent's accusations against the guilt of the redeemed. But this is just one part of the serpent's "works," the part which presupposes the post-lapsarian order-and the "Son of God" came precisely in order to "destroy the works of the devil" (1 Jn. 3:8; cf. Ps. 91:11-13), namely, in the context of 1 John 3, to destroy the works of the devil in defiling God's creation with sin, and of tempting God's people to sin.

It is worth mentioning at this point that Adam, too, is called the "Son of God." Luke 3-4 juxtaposes precisely that Jesus is God's beloved son, in connection (or by contrast) to Adam, the "son of God" (Lk. 3:38). Here's the key observation: if Jesus, the faithful Son of God, came to fulfil what Adam should have fulfilled, and Jesus's mission was to destroy the works of the devil, so, too, would Adam have completed his obedience by destroying the serpent, but without requiring his own death (which presupposes guilt and sin). In other words, what we can infer from the biblical witness is that the obedience that Adam had to offer in order to receive the consummate state is not vague after all, and we can gain some progress toward specifying what that completion must entail. Adam would have completed his obedience if he had destroyed the serpent, banishing him from God's holy garden, by 
resisting the serpent's temptations and by obedience to God's word against him. In traditional Reformed terminology, Adam had to offer active obedience but not passive obedience, whereas Christ had to offer both.

While this response does involve drawing some educated inferences from the biblical witness, and involves the task of disentangling what part of obedience presupposes the fall (passive obedience) and what part is simply original (active obedience), I do not believe that it is reducible to unhealthy speculation. At worst, what is involved here is a speculation of a theologically fruitful kind, and at best I do believe that it's a hypothesis that goes along the grain of the biblical text, in consonance with the Reformed tradition. If this story is plausible (and I submit that it is), then we have a response, too, to the objection from vagueness.

\section{Conclusion}

This essay has summarized one recent argument for IA, and against CA. More specifically, CA agrees that eschatological consummation was the original telos of humanity's creation, but disagrees that the incarnation itself was the essential or necessary means by which humanity would obtain that eschatological end. Hence, there is another way that humanity could obtain that eschatological end apart from Christ, namely, by way of the obedience of Adam, humanity's original federal head, to the stipulations of the covenant of works. This covenantal theology, found within the Reformed tradition, evades the two charges against CA by Mark Cortez, namely that the CA model would seem to entail that grace is unnecessary for humanity to achieve their eschatological end, and that it involves undue speculation. A Reformed CA model argues that (1) the covenant idea grounds the gracious character of their achievement of that supernatural end, had Adam obeyed and (2) shows that no excessive speculation is necessary to show that another way apart from the incarnation was possible to achieve eschatological consummation. I have also responded to two potential objections, further showing how the covenant idea can be fruitfully deployed in this debate.

This essay is by no means definitive, as it does open another array of questions. For one example, this model of CA seems to presuppose the existence of an original individual who functions as the federal head of the rest of humanity in a way consonant with monogenism, or at least the positing of some original humanity that functions federally for the rest of humanity. It also has not considered what Oliver Crisp has called the Christological Union model toward an incarnation anyway thesis (Crisp 2019). Nonetheless, it seeks to at least offer one way forward in the IA debate, in defense of a CA model from the Reformed tradition. ${ }^{4}$

\footnotetext{
${ }^{4}$ I am grateful to J.T. Turner, Murray Smith, and the anonymous reviewers for their feedback.
} 


\section{References}

Adams, Marilyn McCord. 2006. Christ and Horrors: The Coherence of Christology. Cambridge University Press.

Bavinck, Herman. 2004. Reformed Dogmatics. Volume 2. God and Creation, edited by John Bolt. Translated by. John Vriend. Baker Academic.

Cortez, Marc. 2017. Resourcing Theological Anthropology: A Constructive Account of Humanity in the Light of Christ. Zondervan.

Crisp, Oliver. 2019. Analyzing Doctrine: Toward a Systematic Theology. Baylor University Press.

. 2016. "Incarnation Without the Fall." Journal of Reformed Theology 10 (3): 21533.

Turner, James T. 2019. "Perfect Obedience, Perfect Love, and the (So-Called) Problem of Heavenly Freedom." In Love, Divine and Human: Contemporary Essays in Systematic and Philosophical Theology, edited by Oliver Crisp, James M. Arcadi, and Jordan Wesseling. Bloomsbury T\&T Clark.

Turretin, Francis. 1997. Institutes of Elenctic Theology. Volume 1. Edited by James T. Dennison Jr. Translated by. George Musgrave Giger. Presbyterian \& Reformed Publishing.

VanDixhoorn, Chad. 2014. Confessing the Faith: A Reader's Guide to the Westminster Confession of Faith. Banner of Truth.

Van Driel, Edwin. 2008. Incarnation Anyway: Arguments for Supralapsarian Christology. Oxford University Press.

Vos, Geerhardus, 1980. "The Eschatological Aspect of the Pauline Conception of the Spirit." In Redemptive History and Biblical Interpretation: The Shorter Writings of Geerhardus Vos, edited by Richard B. Gaffin. Presbyterian \& Reformed Publishing.

The Westminster Confession of Faith and Catechisms: With Prooftexts. 2005. The Committee on Christian Education of the Orthodox Presbyterian Church. 